\title{
Syntheses of double- and triple-decker clusters of osmium and cobalt metals linked by cyclotetradeca-1,8-diyne ligands
}

\author{
Tsun-Wei Shiue ${ }^{a}$, Wen-Yann Yeh ${ }^{\mathrm{a}, *}$, Gene-Hsiang Lee ${ }^{\mathrm{b}}$, Shie-Ming Peng ${ }^{\mathrm{b}}$ \\ a Department of Chemistry, National Sun Yat-Sen University, Kaohsiung, 70 Lan-Hai Road, Kaohsiung, Taiwan 804 \\ ${ }^{\mathrm{b}}$ Department of Chemistry, National Taiwan University, Taipei, Taiwan 106
}

Received 26 May 2004; accepted 22 July 2004

Available online 23 August 2004

\begin{abstract}
Photoirradiation of $\mathrm{Os}_{3}(\mathrm{CO})_{10}\left(\mathrm{C}_{14} \mathrm{H}_{20}\right)(\mathbf{1})$ in $n$-hexane produces the double-decker cluster $\left[\mathrm{Os}_{3}(\mathrm{CO})_{9}\left(\mathrm{C}_{28} \mathrm{H}_{40}\right)\right]\left[\mathrm{Os}_{3}(\mathrm{CO})_{10}\right](7)$, which can also be prepared from the reaction of $\mathrm{Os}_{3}(\mathrm{CO})_{9}\left(\mathrm{C}_{28} \mathrm{H}_{40}\right)(2)$ and $\mathrm{Os}_{3}(\mathrm{CO})_{10}(\mathrm{NCMe})_{2}$. Further reaction of 7 with $\mathrm{Os}_{3}(\mathrm{CO})_{10}(\mathrm{NCMe})_{2}$ affords the triple-decker cluster $\left[\mathrm{Os}_{3}(\mathrm{CO})_{9}\left(\mathrm{C}_{28} \mathrm{H}_{40}\right)\right]\left[\mathrm{Os}_{3}(\mathrm{CO})_{10}\right]_{2}(8)$. The bis $($ diyne $)$ complex Os$_{3}(\mathrm{CO})_{8}\left(\mathrm{C}_{14} \mathrm{H}_{20}\right)_{2}$ (3) reacts with $\mathrm{Os}_{3}(\mathrm{CO})_{10}(\mathrm{NCMe})_{2}$ sequentially to yield the double-decker cluster $\left[\mathrm{Os}_{3}(\mathrm{CO})_{8}\left(\mathrm{C}_{14} \mathrm{H}_{20}\right)_{2}\right]\left[\mathrm{Os}_{3}(\mathrm{CO})_{10}\right](4)$ and the tripledecker cluster $\left[\mathrm{Os}_{3}(\mathrm{CO})_{8}\left(\mathrm{C}_{14} \mathrm{H}_{20}\right)_{2}\right]\left[\mathrm{Os}_{3}(\mathrm{CO})_{10}\right]_{2}(\mathbf{5})$. Treatment of 3 with $\mathrm{Co}_{2}(\mathrm{CO})_{8}$ at room temperature leads to the mixed-metal triple-decker cluster $\left[\mathrm{Os}_{3}(\mathrm{CO})_{8}\left(\mathrm{C}_{14} \mathrm{H}_{20}\right)_{2}\right]\left[\mathrm{Co}_{2}(\mathrm{CO})_{6}\right]_{2}(6)$, while the reaction of 2 and $\mathrm{Co}_{2}(\mathrm{CO})_{8}$ produces $\left[\mathrm{Os}{ }_{3}(\mathrm{CO})_{9}\left(\mathrm{C}_{28} \mathrm{H}_{40}\right)\right]$ $\left[\mathrm{Co}_{2}(\mathrm{CO})_{6}\right]_{2}(\mathbf{9})$ and $\left[\mathrm{Os}_{2}(\mathrm{CO})_{6}\left(\mathrm{C}_{28} \mathrm{H}_{40}\right)\right]\left[\mathrm{Co}_{2}(\mathrm{CO})_{6}\right]_{2}(\mathbf{1 0})$. Compound 10, which involves cluster degradation from Os 3 to Os $\mathrm{Os}_{2}$, has been structurally characterized by an X-ray diffraction study.
\end{abstract}

(C) 2004 Elsevier B.V. All rights reserved.

Keywords: Cluster; Osmium; Cobalt; Cyclodiyne

\section{Introduction}

Cyclic dialkynes (or cyclodiynes) [1] can react with metal carbonyls to give a wide variety of superphanes and cage compounds [2], or serve as bridging units between homo- or heterometallic centers in organometallic compounds [3]. Recently, to construct higher nuclearity clusters with well-defined dimensions provides a new field of chemistry with prospective application in areas including molecular recognition and nanotechnology [4]. We have prepared the triosmium cyclotetradeca1,8-diyne $\left(\mathrm{C}_{14} \mathrm{H}_{20}\right)$ complexes $\mathrm{Os}_{3}(\mathrm{CO})_{10}\left(\mathrm{C}_{14} \mathrm{H}_{20}\right)$ (1), $\mathrm{Os}_{3}(\mathrm{CO})_{9}\left(\mathrm{C}_{28} \mathrm{H}_{40}\right)$ (2) and $\mathrm{Os}_{3}(\mathrm{CO})_{8}\left(\mathrm{C}_{14} \mathrm{H}_{20}\right)_{2}$ (3) [5], and used these complexes as building blocks to assemble a series of beltlike metallacyclodiyne compounds [6]. In this paper we wish to report the syntheses and character-

\footnotetext{
${ }^{*}$ Corresponding author. Tel.: 886752520003927; fax: 88675253908.

E-mail address: wenyann@mail.nsysu.edu.tw (W.-Y. Yeh).
}

ization of several double- and triple-decker clusters based on the structures of compounds 1-3. The reaction pathways are outlined in Scheme 1.

\section{Results and discussion}

The reaction between cyclotetradeca-1,8-diyne $\left(\mathrm{C}_{14} \mathrm{H}_{20}\right)$ and $\mathrm{Os}_{3}(\mathrm{CO})_{10}(\mathrm{NCMe})_{2}$ has been shown to produce 1 and $\left[\mathrm{Os}_{3}(\mathrm{CO})_{10}\right]_{2}\left(\mathrm{C}_{14} \mathrm{H}_{20}\right)$ [5]. Since compound 3 can be viewed as an $\mathrm{Os}_{3}$-intercalated cyclodiyne, it reacts with $\mathrm{Os}_{3}(\mathrm{CO})_{10}(\mathrm{NCMe})_{2}$ in hot benzene solvent to afford the double-decker cluster $\left[\mathrm{Os}_{3}(\mathrm{CO})_{8}\left(\mathrm{C}_{14} \mathrm{H}_{20}\right)_{2}\right]\left[\mathrm{Os}_{3}(\mathrm{CO})_{10}\right](4)$ and the triple-decker cluster $\left[\mathrm{Os}_{3}(\mathrm{CO})_{8}\left(\mathrm{C}_{14} \mathrm{H}_{20}\right)_{2}\right]\left[\mathrm{Os}_{3}(\mathrm{CO})_{10}\right]_{2}$ (5) sequentially. On the other hand, reaction of 3 with two equivalents of $\mathrm{Co}_{2}(\mathrm{CO})_{8}$ at ambient temperature affords the mixed-metal cluster $\left[\mathrm{Os}_{3}(\mathrm{CO})_{8}\left(\mathrm{C}_{14} \mathrm{H}_{20}\right)_{2}\right]\left[\mathrm{Co}_{2}(\mathrm{CO})_{6}\right]_{2}$ (6) in good isolated yield. 


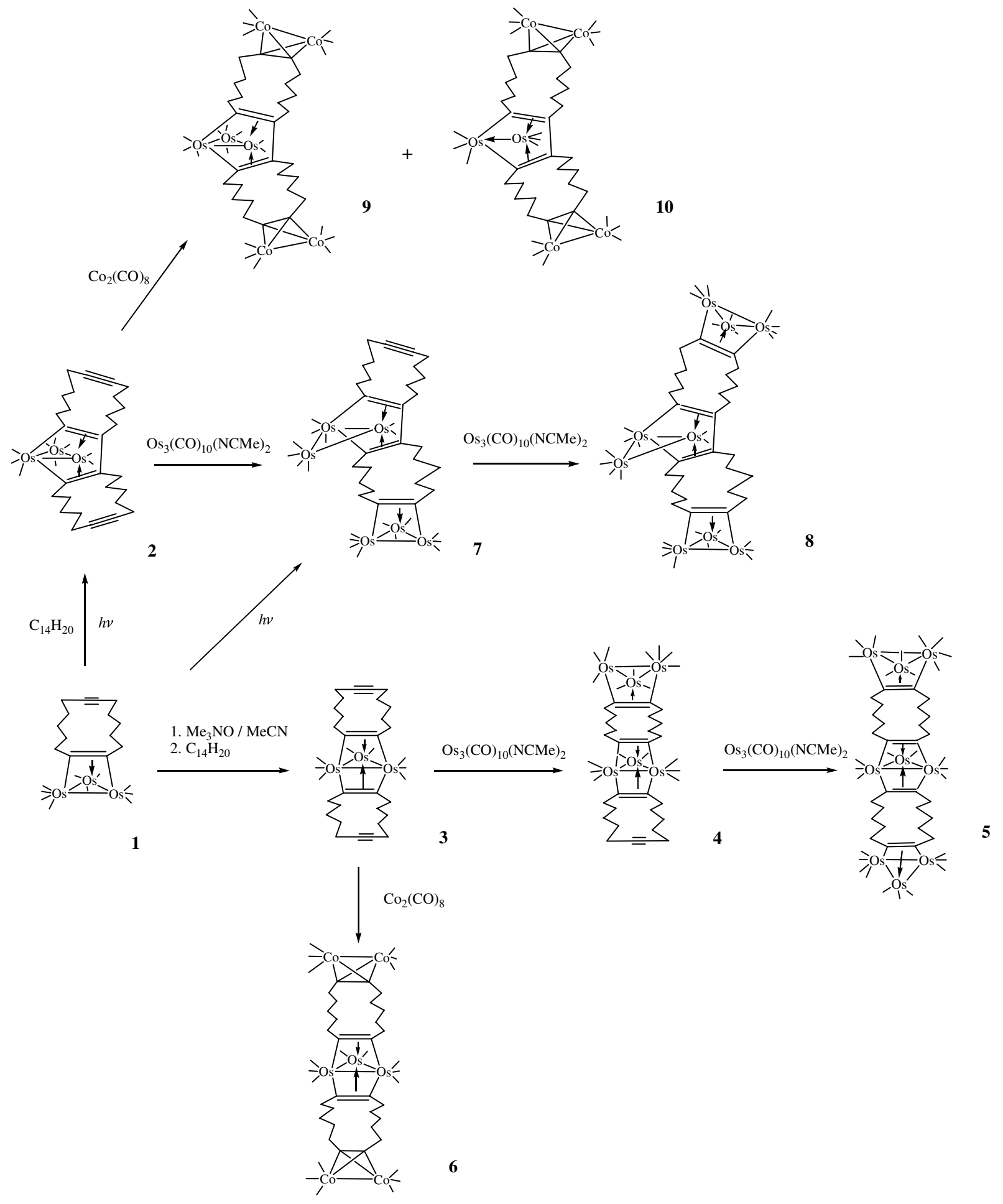

Scheme 1 .

Previously, the osmacyclopentadienyl complex 2 was obtained from photoirradiation of $\mathbf{1}$ in the presence of $\mathrm{C}_{14} \mathrm{H}_{20}$ ligand [5]. Since compound $\mathbf{1}$ contains a pendant alkyne moiety and an open $\mathrm{Os}_{3}$ face, irradiation of $\mathbf{1}$ itself results in an intermolecular alkyne-insertion to generate the double-decker cluster $\left[\mathrm{Os}_{3}(\mathrm{CO})_{9}\left(\mathrm{C}_{28} \mathrm{H}_{40}\right)\right]$
$\left[\mathrm{Os}_{3}(\mathrm{CO})_{10}\right]$ (7). This reaction, however, was carried out for a short period $(1 \mathrm{~h})$ to recover 1 in $81 \%$, while extending the irradiation time did not improve the yield of 7 but leading to a complex mixture, which is likely due to continuous photoreactions of the products. An alternative method to make 7 is by treating 2 with 
$\mathrm{Os}_{3}(\mathrm{CO})_{10}(\mathrm{NCMe})_{2}$ at $60^{\circ} \mathrm{C}$ for $20 \mathrm{~min}$. Further reaction of 7 and $\mathrm{Os}_{3}(\mathrm{CO})_{10}(\mathrm{NCMe})_{2}$ affords the triple-decker cluster $\left[\mathrm{Os}_{3}(\mathrm{CO})_{9}\left(\mathrm{C}_{28} \mathrm{H}_{40}\right)\right]\left[\mathrm{Os}_{3}(\mathrm{CO})_{10}\right]_{2}(\mathbf{8})$, where the two ending alkyne groups of $\mathbf{2}$ are each coordinated to an $\mathrm{Os}_{3}(\mathrm{CO})_{10}$ species. On the other hand, compound 2 reacts with a slight excess of $\mathrm{Co}_{2}(\mathrm{CO})_{8}$ at ambient temperature to produce the mixed-metal triple-decker clusters $\left[\mathrm{Os}_{3}(\mathrm{CO})_{9}\left(\mathrm{C}_{28} \mathrm{H}_{40}\right)\right]\left[\mathrm{Co}_{2}(\mathrm{CO})_{6}\right]_{2}$ (9) and $\left[\mathrm{Os}_{2}(\mathrm{CO})_{6^{-}}\right.$ $\left.\left(\mathrm{C}_{28} \mathrm{H}_{40}\right)\right]\left[\mathrm{Co}_{2}(\mathrm{CO})_{6}\right]_{2}(\mathbf{1 0})$, with the formation of $\mathbf{1 0}$ involving nuclear degradation from a triosmium into a diosmium linkage.

The new compounds $\mathbf{4 - 1 0}$ form stable, colored solids, where 4 and 5 are yellow, 7 and 8 are green, and 6,9 and 10 are brown. Their solubility in organic solvents decreases as the ending alkyne moieties are coordinated to the $\mathrm{Os}_{3}(\mathrm{CO})_{10}$ cluster, such that $\mathbf{2}$ and $\mathbf{3}$ are soluble in $n$-hexane, $\mathbf{4}$ and $\mathbf{7}$ are soluble in benzene and dichloromethane but slightly soluble in $n$-hexane, while $\mathbf{5}$ and 8 show a poor solubility in dichloromethane and THF. On the contrary, the dicobalt-capped clusters $\mathbf{6 , 9}$ and 10 are plenty soluble in common organic solvents. The IR spectra in the carbonyl region for $\mathbf{4}$ and $\mathbf{5}$ are apparently the combination of the spectra of $\mathbf{3}$ and $\mathbf{1}$, and for $\mathbf{7}$ and $\mathbf{8}$ are the combination of $\mathbf{2}$ and $\mathbf{1}$.

Compound 4 exhibits the expected $C_{S}$ symmetry in solution. Its ${ }^{13} \mathrm{C}\left\{{ }^{1} \mathrm{H}\right\}$ NMR spectrum displays four signals for the carbonyl carbons of $\mathrm{Os}_{3}(\mathrm{CO})_{8}$ moiety, one broad signal for the fluxional carbonyl carbons of $\mathrm{Os}_{3}(\mathrm{CO})_{10}$ moiety [7], three signals at $168.2,166.9$ and $148.3 \mathrm{ppm}$ for the coordinated alkyne carbons, one signal at $80.5 \mathrm{ppm}$ for the pendant alkyne carbons, and ten signals in the range 52.7-18.1 ppm for the methylene carbons. In contrast, the bending configuration of 7 gives no symmetry, such that its ${ }^{13} \mathrm{C}\left\{{ }^{1} \mathrm{H}\right\}$ NMR spectrum presents 28 carbon resonances for the $\mathrm{C}_{28} \mathrm{H}_{40}$ ligand. The ${ }^{13} \mathrm{C}\left\{{ }^{1} \mathrm{H}\right\}$ NMR spectrum of 6 depicts one carbonyl signal for the $\mathrm{Co}_{2}(\mathrm{CO})_{6}$ group, three carbonyl signals for the $\mathrm{Os}_{3}(\mathrm{CO})_{8}$ group, two signals at 165.9 and $98.1 \mathrm{ppm}$ for the alkyne carbons bonded to the Os and Co atoms, respectively, and five signals in the range 51.4-27.9 ppm for the methylene carbons, consistent with a $C_{2 v}$ symmetry for the proposed structure (Scheme 1). The ${ }^{13} \mathrm{C}\left\{{ }^{1} \mathrm{H}\right\}$ NMR spectra of $\mathbf{9}$ and $\mathbf{1 0}$ are compatible in the organic ligand region to show two signals for the osmacyclopentadienyl carbons, two signals for the alkyne carbons bonded to the Co atoms, and ten signals for the methylene carbons, in agreement with the proposed structures with a time-averaged $C_{S}$ symmetry in solution. Although the ${ }^{13} \mathrm{C}$ NMR and FAB mass spectra for $\mathbf{5}$ and $\mathbf{8}$ are not obtainable due to a poor solubility in organic solvents, their constitution and configuration can be assigned on the basis of elemental analyses and the IR spectra in comparison with compounds $2,4,7$ and $\left[\mathrm{Os}_{3}(\mathrm{CO})_{10}\right]_{2}\left(\mathrm{C}_{28} \mathrm{H}_{40}\right)$ [5].

Compound 10 forms dark-red crystals. The ORTEP diagram of $\mathbf{1 0}$ is shown in Fig. 1, and the selected bond distances and bond angles are collected in Table 1. The molecule consists of a $\mathrm{C}_{4}\left(\mathrm{C}_{12} \mathrm{H}_{20}\right)_{2}$ link, which is connected with a $\mathrm{Os}_{2}(\mathrm{CO})_{6}$ group in the middle and two $\mathrm{Co}_{2}(\mathrm{CO})_{6}$ groups at the ending sites. The osmium and cobalt atoms are each associated with three terminal carbonyl ligands, with the $\mathrm{M}-\mathrm{C}-\mathrm{O}$ angles in the range 174(2)-179(1) ${ }^{\circ}$. The Os(1) atom and the diene C(19)$\mathrm{C}(22)$ atoms are coplanar to within $\pm 0.02 \AA$, yielding

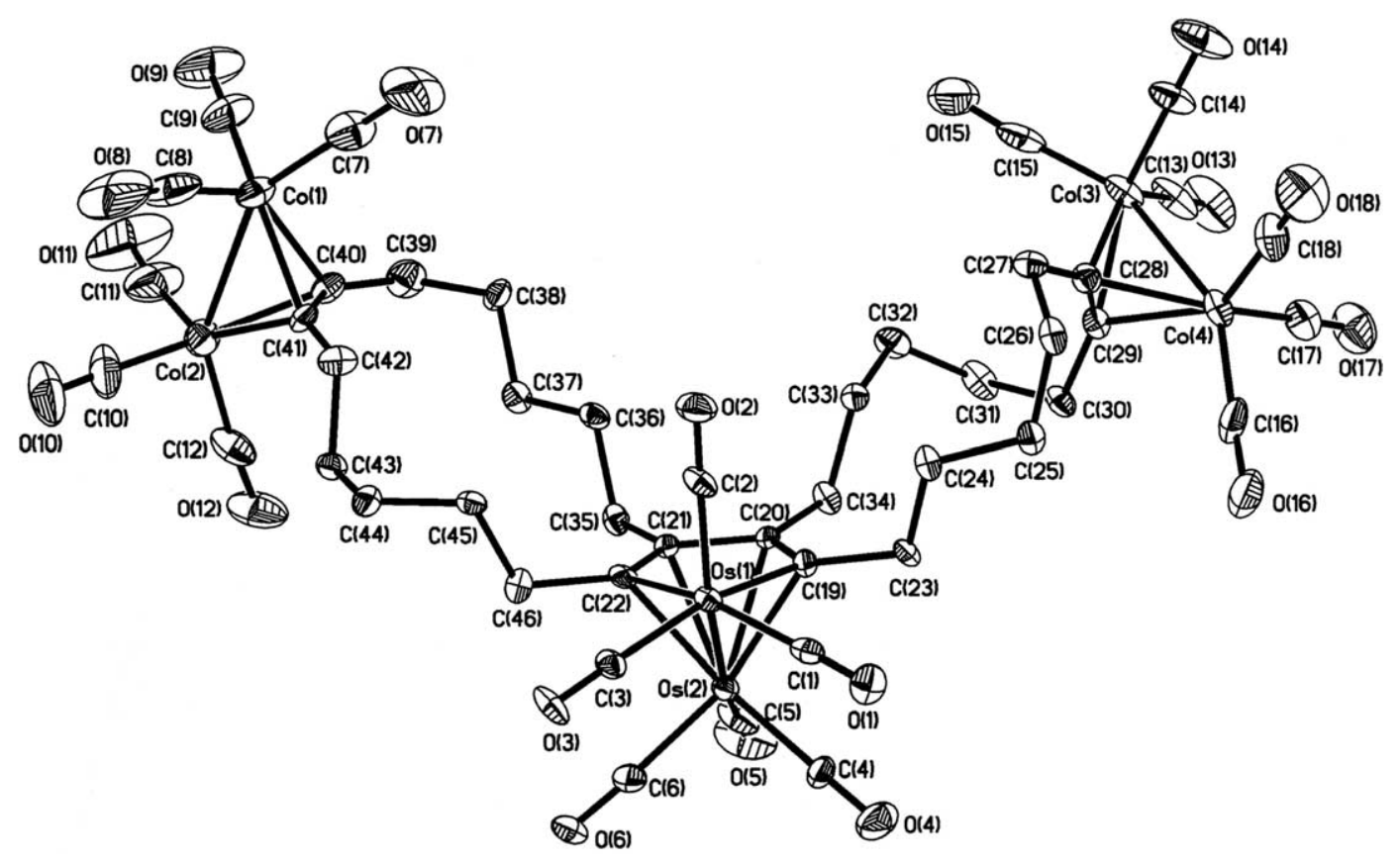

Fig. 1. ORTEP drawing of 10. Thermal ellipsoids are drawn at the $30 \%$ probability level. 
Table 1

Selected bond distances $(\AA)$ and bond angles $\left({ }^{\circ}\right)$ for $\mathbf{1 0}$

\begin{tabular}{llll}
\hline Bond distances & & & \\
\hline Os(1)-Os(2) & $2.7551(5)$ & $\mathrm{Os}(1)-\mathrm{C}(19)$ & $2.095(9)$ \\
Os(1)-C(22) & $2.090(9)$ & $\mathrm{Os}(2)-\mathrm{C}(19)$ & $2.322(8)$ \\
$\mathrm{Os}(2)-\mathrm{C}(20)$ & $2.265(9)$ & $\mathrm{Os}(2)-\mathrm{C}(21)$ & $2.255(9)$ \\
$\mathrm{Os}(2)-\mathrm{C}(22)$ & $2.314(9)$ & $\mathrm{C}(19)-\mathrm{C}(20)$ & $1.401(13)$ \\
$\mathrm{C}(20)-\mathrm{C}(21)$ & $1.466(12)$ & $\mathrm{C}(21)-\mathrm{C}(22)$ & $1.429(13)$ \\
$\mathrm{Co}(1)-\mathrm{Co}(2)$ & $2.461(2)$ & $\mathrm{Co}(3)-\mathrm{Co}(4)$ & $2.463(2)$ \\
$\mathrm{Co}(1)-\mathrm{C}(40)$ & $1.966(10)$ & $\mathrm{Co}(1)-\mathrm{C}(41)$ & $1.968(10)$ \\
$\mathrm{Co}(2)-\mathrm{C}(40)$ & $1.958(11)$ & $\mathrm{Co}(2)-\mathrm{C}(41)$ & $1.969(10)$ \\
$\mathrm{Co}(3)-\mathrm{C}(28)$ & $1.990(10)$ & $\mathrm{Co}(3)-\mathrm{C}(29)$ & $1.968(9)$ \\
$\mathrm{Co}(4)-\mathrm{C}(28)$ & $1.983(10)$ & $\mathrm{Co}(4)-\mathrm{C}(29)$ & $1.970(9)$ \\
$\mathrm{C}(28)-\mathrm{C}(29)$ & $1.303(13)$ & $\mathrm{C}(40)-\mathrm{C}(41)$ & $1.314(14)$ \\
& & & \\
Bond angles & & & $116.3(7)$ \\
$\mathrm{C}(19)-\mathrm{Os}(1)-\mathrm{C}(22)$ & $77.8(4)$ & $\mathrm{C}(20)-\mathrm{C}(19)-\mathrm{Os}(1)$ & $112.6(8)$ \\
$\mathrm{C}(19)-\mathrm{C}(20)-\mathrm{C}(21)$ & $115.9(8)$ & $\mathrm{C}(22)-\mathrm{C}(21)-\mathrm{C}(20)$ & \\
$\mathrm{C}(21)-\mathrm{C}(22)-\mathrm{Os}(1)$ & $117.3(6)$ & $\mathrm{C}(19)-\mathrm{Os}(1)-\mathrm{Os}(2)$ & $55.2(2)$ \\
$\mathrm{C}(19)-\mathrm{Os}(2)-\mathrm{Os}(1)$ & $47.8(2)$ & $\mathrm{Os}(1)-\mathrm{C}(19)-\mathrm{Os}(2)$ & $77.0(3)$ \\
$\mathrm{C}(22)-\mathrm{Os}(1)-\mathrm{Os}(2)$ & $55.0(2)$ & $\mathrm{C}(22)-\mathrm{Os}(2)-\mathrm{Os}(1)$ & $47.7(2)$ \\
$\mathrm{Os}(1)-\mathrm{C}(22)-\mathrm{Os}(2)$ & $77.3(3)$ & $\mathrm{C}(21)-\mathrm{Os}(2)-\mathrm{C}(22)$ & $36.4(3)$ \\
$\mathrm{C}(22)-\mathrm{C}(21)-\mathrm{Os}(2)$ & $74.0(5)$ & $\mathrm{C}(21)-\mathrm{C}(22)-\mathrm{Os}(2)$ & $69.6(5)$ \\
$\mathrm{C}(21)-\mathrm{Os}(2)-\mathrm{C}(20)$ & $37.8(3)$ & $\mathrm{C}(21)-\mathrm{C}(20)-\mathrm{Os}(2)$ & $70.7(5)$ \\
$\mathrm{C}(20)-\mathrm{C}(21)-\mathrm{Os}(2)$ & $71.4(5)$ & $\mathrm{C}(20)-\mathrm{Os}(2)-\mathrm{C}(19)$ & $35.5(3)$ \\
$\mathrm{C}(20)-\mathrm{C}(19)-\mathrm{Os}(2)$ & $70.0(5)$ & $\mathrm{C}(19)-\mathrm{C}(20)-\mathrm{Os}(2)$ & $74.4(5)$ \\
\hline
\end{tabular}

an osmacyclopentadienyl framework [8]. Thus, the coordination about the Os(1) atom can be described as a distorted octahedron, and the Os(2) atom as a three-legged piano stool by considering the metallacycle as an $\eta^{5}$ ligand. The Os(1)-Os(2) length is 2.7551(5) $\AA$, typical of an osmium-osmium single bond, while the $\mathrm{C}_{(19-22)}-\mathrm{Os}(2)$ distances show substantial variation, ranging from 2.255(9) to 2.322(8) $\AA$. The alkyne $C(28)-C(29)$ and $\mathrm{C}(40)-\mathrm{C}(41)$ units apparently donate four $\pi$-electrons to each dicobalt system in a $\perp$-bonding mode to give a

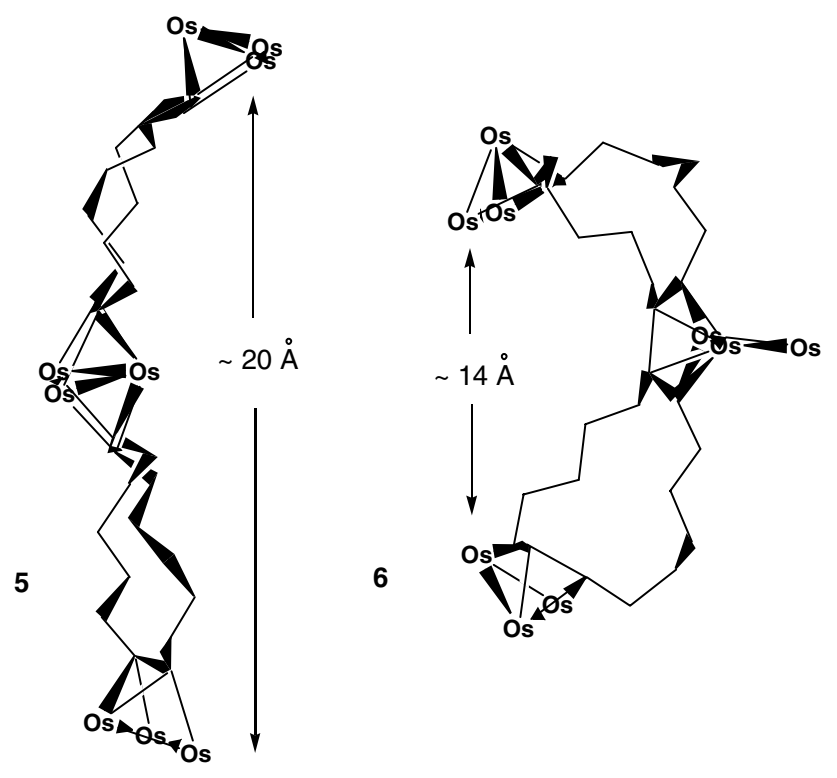

Scheme 2. quasi-tetrahedral core with the averaged $\mathrm{C}-\mathrm{Co}$ distances of $1.97 \AA$. The $\mathrm{Co}(1)-\mathrm{Co}(2)$ and $\mathrm{Co}(3)-\mathrm{Co}(4)$ lengths are equal, being $2.46 \AA$.

In summary, compounds $\mathbf{2}$ and $\mathbf{3}$ can react with $\mathrm{Os}_{3}(\mathrm{CO})_{10}(\mathrm{NCMe})_{2}$ and $\mathrm{Co}_{2}(\mathrm{CO})_{8}$ to give the doubleand triple-decker clusters $\mathbf{4 - 1 0}$, which are of interest within the context of supramolecular chemistry [9]. The lengths of these triple cluster compounds are $1-2 \mathrm{~nm}$, such that the two $\mathrm{Co}_{2}$ units in $\mathbf{1 0}$ are separated by $13 \AA$, and the distances between the two ending $\mathrm{Os}_{3}$ groups are estimated to be 20 and $14 \AA$ for $\mathbf{5}$ and $\mathbf{6}$, respectively (Scheme 2). It is promising that further treatment of $\mathbf{5}$ with $\mathrm{Me}_{3} \mathrm{NO} / \mathrm{MeCN}$ or photoirradiation of 8 in the presence of $\mathrm{C}_{14} \mathrm{H}_{20}$ ligand can lead to higher nuclearity cluster oligmers with a straight or curled metallacyclic chain. The investigation is in progress in our laboratory.

\section{Experimental}

All manipulations were carried out under an atmosphere of purified dinitrogen with standard Schlenk techniques [10]. Cyclotetradeca-1,8-diene $\left(\mathrm{C}_{14} \mathrm{H}_{20}\right)$ [11], $\mathrm{Os}_{3}(\mathrm{CO})_{10}(\mathrm{NCMe})_{2} \quad$ [12], $\mathrm{Os}_{3}(\mathrm{CO})_{10}\left(\mathrm{C}_{14} \mathrm{H}_{20}\right)$ (1) [5], $\mathrm{Os}_{3}(\mathrm{CO})_{9}\left(\mathrm{C}_{28} \mathrm{H}_{40}\right)$ (2) [5], and $\mathrm{Os}_{3}(\mathrm{CO})_{8}\left(\mathrm{C}_{14} \mathrm{H}_{20}\right)_{2}$ (3) [6] were prepared by literature methods. $\mathrm{Co}_{2}(\mathrm{CO})_{8}$ (from Strem) was used as received. Solvents were dried over appropriate reagents under dinitrogen and distilled immediately before use. Preparative thin-layer chromatographic (TLC) plates were prepared from silica gel (Merck). Infrared spectra were recorded with a 0.1 $\mathrm{mm}$ path-length $\mathrm{CaF}_{2}$ solution cell on a Hitachi I-2001 IR spectrometer. ${ }^{1} \mathrm{H}$ and ${ }^{13} \mathrm{C}$ NMR spectra were obtained on a Varian Unity INOVA-500 spectrometer at 500 and $125.7 \mathrm{MHz}$, respectively. Fast-atom-bombardment (FAB) mass spectra were recorded on a VG Blotch-5022 or a JEOL JMS-SX102A mass spectrometer. Elemental analyses were performed at the National Science Council Regional Instrumentation Center at National Chen-Kung University, Tainan, Taiwan.

\subsection{Photoirradiation of 1 to give 7}

This reaction was carried out in an ACE microscale photoreaction vessel equipped with an immersed PenRay 5.5 W low-pressure, cold cathode, mercury gaseous discharge lamp. $\mathrm{Os}_{3}(\mathrm{CO})_{10}\left(\mathrm{C}_{14} \mathrm{H}_{20}\right)(\mathbf{1} ; 100 \mathrm{mg}, 0.096$ mmol) was dissolved in $n$-hexane $(15 \mathrm{ml})$ and the solution was irradiated for $1 \mathrm{~h}$ with dinitrogen slowly bubbling through the solution. During the reaction, the solution color changed gradually from orange to grayyellow. The solvent was removed on a rotary evaporator, and the residue was subjected to TLC, with $\mathrm{CH}_{2} \mathrm{Cl}_{2} / n$-hexane as eluent $(1: 4, \mathrm{v} / \mathrm{v})$. The unreacted compound $1(81 \mathrm{mg})$ was recovered from the first yellow band. The major green band yielded $\left[\mathrm{Os}_{3}(\mathrm{CO})_{9^{-}}\right.$ 
$\left.\left(\mathrm{C}_{28} \mathrm{H}_{40}\right)\right]\left[\mathrm{Os}_{3}(\mathrm{CO})_{10}\right](7 ; 11 \mathrm{mg}, 59 \%$ based on 1 consumed). Anal. Calc. for $\mathrm{C}_{47} \mathrm{H}_{40} \mathrm{O}_{19} \mathrm{Os}_{6}: \mathrm{C}, 27.51 ; \mathrm{H}$, 1.95. Found: C, 27.55; H, 2.40\%. MS (FAB): $m / z 2048$ $\left(\mathrm{M}^{+},{ }^{190} \mathrm{Os}\right)$. IR $\left(\mathrm{CH}_{2} \mathrm{Cl}_{2}, v_{\mathrm{CO}}\right): 2100 \mathrm{~m}, 2060 \mathrm{~s}, 2040 \mathrm{vs}$, 2012s, 1994vs, 1964s, 1918w cm ${ }^{-1}$. ${ }^{1} \mathrm{H}$ NMR $\left(\mathrm{CDCl}_{3}\right.$, $\left.23{ }^{\circ} \mathrm{C}\right): \quad 3.30-1.27\left(\mathrm{~m}, \mathrm{CH}_{2}\right)$ ppm. ${ }^{13} \mathrm{C}\left\{{ }^{1} \mathrm{H}\right\} \quad \mathrm{NMR}$ $\left(\mathrm{C}_{6} \mathrm{D}_{6}, 23{ }^{\circ} \mathrm{C}\right): 178.2,176.0,175.9\left(\mathrm{Os}_{3}(\mathrm{CO})_{9}\right), 177.2$ $\left(\mathrm{br}, \mathrm{Os}_{3}(\mathrm{CO})_{10}\right), 173.7,165.3,128.5,126.3\left(\mu-\mathrm{C}_{4} \mathrm{Os}\right)$, 148.8, $\quad 148.4 \quad\left(\mathrm{C} \equiv \mathrm{C}-\mathrm{Os}_{3}(\mathrm{CO})_{10}\right), \quad 82.5, \quad 80.1 \quad$ (free $\mathrm{C} \equiv \mathrm{C}), 53.7, \quad 51.5,50.2,45.1,43.9,36.9,34.3,33.8$, $32.6,32.0,31.7,31.3,29.6,28.9,28.5,28.2,27.8,26.6$, 19.4, $17.6\left(\mathrm{CH}_{2}\right) \mathrm{ppm}$.

\subsection{Preparation of 7 from 2 and $\mathrm{Os}_{3}(\mathrm{CO})_{10}(\mathrm{NCMe})_{2}$}

$\mathrm{Os}_{3}(\mathrm{CO})_{9}\left(\mathrm{C}_{28} \mathrm{H}_{40}\right) \quad(2 ; 20 \mathrm{mg}, 0.017 \mathrm{mmol})$ and $\mathrm{Os}_{3}(\mathrm{CO})_{10}(\mathrm{NCMe})_{2}(11 \mathrm{mg}, 0.012 \mathrm{mmol})$ were dissolved in benzene $(10 \mathrm{ml})$ and the solution was heated at $60{ }^{\circ} \mathrm{C}$ for $20 \mathrm{~min}$. After cooling the solution to ambient temperature, the solvent was removed on a rotary evaporator and the residue was subjected to TLC, with $\mathrm{CH}_{2} \mathrm{Cl}_{2}$ / $n$-hexane $(1: 4, \mathrm{v} / \mathrm{v})$ as eluent. The starting compound 2 $(10 \mathrm{mg})$ was recovered from the first blue band. The second green band afforded compound $7(12 \mathrm{mg}, 70 \%$ based on $\mathbf{2}$ consumed).

\subsection{Preparation of $\boldsymbol{8}$ from 2 and $\mathrm{Os}_{3}(\mathrm{CO})_{10}(\mathrm{NCMe})_{2}$}

$\mathrm{Os}_{3}(\mathrm{CO})_{9}\left(\mathrm{C}_{28} \mathrm{H}_{40}\right) \quad(2 ; 15 \mathrm{mg}, 0.012 \mathrm{mmol})$ and $\mathrm{Os}_{3}(\mathrm{CO})_{10}(\mathrm{NCMe})_{2}(45 \mathrm{mg}, 0.048 \mathrm{mmol})$ were dissolved in benzene $(20 \mathrm{ml})$. The solution was heated at $60{ }^{\circ} \mathrm{C}$ for 20 min, yielding a green precipitate. The precipitate was collected by filtration and washed with benzene to give $\left[\mathrm{Os}_{3}(\mathrm{CO})_{9}\left(\mathrm{C}_{28} \mathrm{H}_{40}\right)\right]\left[\mathrm{Os}_{3}(\mathrm{CO})_{10}\right]_{2}(\mathbf{8} ; 24 \mathrm{mg}, 69 \%)$. Anal. Calc. For $\mathrm{C}_{57} \mathrm{H}_{40} \mathrm{O}_{29} \mathrm{Os}_{9}$ : C, 23.60; H, 1.38. Found: C, $23.92 ; \mathrm{H}, 1.47 \%$. IR $\left(\mathrm{CH}_{2} \mathrm{Cl}_{2}, v_{\mathrm{CO}}\right): 2100 \mathrm{~m}, 2060 \mathrm{~s}$, 2040vs, 2012s, 1994vs, 1964s, 1918w cm ${ }^{-1}$.

\subsection{Preparation of 8 from 7 and $\mathrm{Os}_{3}(\mathrm{CO})_{10}(\mathrm{NCMe})_{2}$}

Compound $7 \quad(5 \quad \mathrm{mg}, \quad 0.0024 \mathrm{mmol})$ and $\mathrm{Os}_{3}(\mathrm{CO})_{10}(\mathrm{NCMe})_{2}(5 \mathrm{mg}, 0.005 \mathrm{mmol})$ were dissolved in benzene $(3 \mathrm{ml})$. The solution was heated at $60{ }^{\circ} \mathrm{C}$ for $20 \mathrm{~min}$, yielding a green precipitate of $8(5 \mathrm{mg}, 72 \%)$.

\subsection{Preparation of 4 from 3 and $\mathrm{Os}_{3}(\mathrm{CO})_{10}(\mathrm{NCMe})_{2}$}

$\mathrm{Os}_{3}(\mathrm{CO})_{8}\left(\mathrm{C}_{14} \mathrm{H}_{20}\right)_{2} \quad(3 ; 40 \mathrm{mg}, 0.034 \mathrm{mmol})$ and $\mathrm{Os}_{3}(\mathrm{CO})_{10}(\mathrm{NCMe})_{2}(22 \mathrm{mg}, 0.024 \mathrm{mmol})$ were dissolved in benzene $(20 \mathrm{ml})$ and the solution was heated at $60{ }^{\circ} \mathrm{C}$ for $20 \mathrm{~min}$. The solvent was removed on a rotary evaporator and the residue was subjected to TLC, with $\mathrm{CH}_{2} \mathrm{Cl}_{2} / n$-hexane $(1: 4, \mathrm{v} / \mathrm{v})$ as eluent. The unreacted compound $3(19 \mathrm{mg})$ was recovered from the first yellow band. The second yellow band afforded $\left[\mathrm{Os}_{3}(\mathrm{CO})_{8-}\right.$ $\left.\left(\mathrm{C}_{14} \mathrm{H}_{20}\right)_{2}\right]\left[\mathrm{Os}_{3}(\mathrm{CO})_{10}\right] \quad(4 ; 25 \mathrm{mg}, 69 \%$ based on 3 consumed). Anal. Calc. for $\mathrm{C}_{46} \mathrm{H}_{40} \mathrm{O}_{18} \mathrm{Os}_{6}$ : C, 27.32; $\mathrm{H}, 1.99$. Found: $\mathrm{C}, 27.75 ; \mathrm{H}, 2.07 \%$. MS (FAB): $\mathrm{m} / \mathrm{z}$ $2020\left(\mathrm{M}^{+},{ }^{190} \mathrm{Os}\right)$. IR $\left(\mathrm{CH}_{2} \mathrm{Cl}_{2}, v_{\mathrm{CO}}\right): 2100 \mathrm{w}, 2080 \mathrm{~m}$, 2060s, 2040vs, 2012vs, 2000vs, 1972m, 1936w cm ${ }^{-1} .{ }^{1} \mathrm{H}$ NMR $\left(\mathrm{CDCl}_{3}, 23{ }^{\circ} \mathrm{C}\right): 3.83(\mathrm{~m}, 2 \mathrm{H}), 3.59(\mathrm{~m}, 2 \mathrm{H})$, $3.47(\mathrm{~m}, 2 \mathrm{H}), 3.20(\mathrm{~m}, 2 \mathrm{H}), 3.08(\mathrm{~m}, 2 \mathrm{H}), 2.30(\mathrm{~m}$, $6 \mathrm{H}), 2.13(\mathrm{~m}, 6 \mathrm{H}), 1.76-1.51(\mathrm{~m}, 18 \mathrm{H}) \mathrm{ppm} .{ }^{13} \mathrm{C}\left\{{ }^{1} \mathrm{H}\right\}$ NMR $\left(\mathrm{CDCl}_{3}, 23{ }^{\circ} \mathrm{C}\right): 181.0,178.7,178.5,165.8$ $\left(\mathrm{Os}_{3}(\mathrm{CO})_{8}\right), \quad 176.9 \quad\left(\mathrm{br}, \quad \mathrm{Os}_{3}(\mathrm{CO})_{10}\right), \quad 168.2, \quad 166.9$ $\left(\mathrm{C} \equiv \mathrm{C}-\mathrm{Os}_{3}(\mathrm{CO})_{8}\right), 148.3\left(\mathrm{C} \equiv \mathrm{C}-\mathrm{Os}_{3}(\mathrm{CO})_{10}\right), 80.5$ (free $\mathrm{C} \equiv \mathrm{C}), 52.7,50.9,49.4,34.3,33.9,33.0,28.6,27.9,26.5$, $18.1\left(\mathrm{CH}_{2}\right) \mathrm{ppm}$.

\subsection{Preparation of 5 from 3 and $\mathrm{Os}_{3}(\mathrm{CO})_{10}(\mathrm{NCMe})_{2}$}

$\mathrm{Os}_{3}(\mathrm{CO})_{8}\left(\mathrm{C}_{14} \mathrm{H}_{20}\right)_{2} \quad(3 ; 19 \mathrm{mg}, 0.016 \mathrm{mmol})$ and $\mathrm{Os}_{3}(\mathrm{CO})_{10}(\mathrm{NCMe})_{2}(60 \mathrm{mg}, 0.064 \mathrm{mmol})$ were dissolved in benzene $(25 \mathrm{ml})$. The solution was heated at $60^{\circ} \mathrm{C}$ for $20 \mathrm{~min}$, yielding a yellow precipitate. The precipitate was collected by filtration, and washed with benzene to give $\left[\mathrm{Os}_{3}(\mathrm{CO})_{8}\left(\mathrm{C}_{14} \mathrm{H}_{20}\right)_{2}\right]\left[\mathrm{Os}_{3}(\mathrm{CO})_{10}\right]_{2}(\mathbf{5} ; 40 \mathrm{mg}, 87 \%)$. Anal. Calc. for $\mathrm{C}_{56} \mathrm{H}_{40} \mathrm{O}_{28} \mathrm{Oss}_{9}$ : C, 23.41; H, 1.40. Found: C, 23.74; H, $1.65 \%$. IR $\left(\mathrm{CH}_{2} \mathrm{Cl}_{2}, v_{\mathrm{CO}}\right): 2100 \mathrm{w}, 2080 \mathrm{~m}$, 2060s, 2040vs, 2012vs, 2000vs, 1972m, 1936w cm ${ }^{-1}$.

\subsection{Preparation of 5 from 4 and $\mathrm{Os}_{3}(\mathrm{CO})_{10}(\mathrm{NCMe})_{2}$}

Compound $4 \quad(5 \quad \mathrm{mg}, \quad 0.0025 \mathrm{mmol})$ and $\mathrm{Os}_{3}(\mathrm{CO})_{10}(\mathrm{NCMe})_{2}(5 \mathrm{mg}, 0.005 \mathrm{mmol})$ were dissolved in benzene $(3 \mathrm{ml})$. The solution was heated at $60{ }^{\circ} \mathrm{C}$ for $20 \mathrm{~min}$ to yield a yellow precipitate, characterized as $\mathbf{5}(6 \mathrm{mg}, 84 \%)$.

\subsection{Preparation of 6}

$\mathrm{Os}_{3}(\mathrm{CO})_{8}\left(\mathrm{C}_{14} \mathrm{H}_{20}\right)_{2} \quad(3 ; 25 \mathrm{mg}, 0.021 \mathrm{mmol})$ and $\mathrm{Co}_{2}(\mathrm{CO})_{8}(18 \mathrm{mg}, 0.053 \mathrm{mmol})$ were dissolved in $n$-hexane $(35 \mathrm{ml})$ and the solution was stirred at ambient temperature for $1 \mathrm{~h}$. The solvent was evaporated and the residue was subjected to TLC, with $n$-hexane as eluent. The major brown band afforded $\left[\mathrm{Os}_{3}(\mathrm{CO})_{8}\left(\mathrm{C}_{14} \mathrm{H}_{20}\right)_{2}\right]$ $\left[\mathrm{Co}_{2}(\mathrm{CO})_{6}\right]_{2}(6 ; 30 \mathrm{mg}, 82 \%)$. Anal. Calc. for $\mathrm{C}_{48} \mathrm{H}_{40} \mathrm{O}_{20}-$ $\mathrm{Co}_{4} \mathrm{Os}_{3}$ : C, 33.06; H, 2.31. Found: C, 33.27; H, 2.60\%. IR $\left(\mathrm{CH}_{2} \mathrm{Cl}_{2}, v_{\mathrm{CO}}\right): 2084 \mathrm{~m}, 2044 \mathrm{vs}, 2012 \mathrm{vs}, 2000 \mathrm{vs}$, $1970 \mathrm{~m}, 1936 \mathrm{w} \mathrm{cm}{ }^{-1} .{ }^{1} \mathrm{H}$ NMR $\left(\mathrm{CDCl}_{3}, 23{ }^{\circ} \mathrm{C}\right): 3.64$ $(\mathrm{m}, 4 \mathrm{H}), 3.58(\mathrm{~m}, 4 \mathrm{H}), 3.04(\mathrm{~m}, 8 \mathrm{H}), 1.90(\mathrm{~m}, 8 \mathrm{H})$, $1.80(\mathrm{~m}, 8 \mathrm{H}), 1.68(\mathrm{~m}, 4 \mathrm{H}), 1.63(\mathrm{~m}, 4 \mathrm{H})$ ppm. ${ }^{13} \mathrm{C}\left\{{ }^{1} \mathrm{H}\right\}$ NMR $\left(\mathrm{CDCl}_{3}, 23{ }^{\circ} \mathrm{C}\right): 200.3(\mathrm{OC}-\mathrm{Co}), 181.0$, 178.6, $\quad 165.8 \quad(\mathrm{OC}-\mathrm{Os}), \quad 165.9\left(\mathrm{C} \equiv \mathrm{C}-\mathrm{Os}_{3}\right), \quad 98.1$ $\left(\mathrm{C} \equiv \mathrm{C}-\mathrm{Co}_{2}\right), 51.4,34.2,31.6,30.7,27.9\left(\mathrm{CH}_{2}\right) \mathrm{ppm}$.

\subsection{Reaction of 2 and $\mathrm{Co}_{2}(\mathrm{CO})_{8}$}

$\mathrm{Os}_{3}(\mathrm{CO})_{9}\left(\mathrm{C}_{28} \mathrm{H}_{40}\right) \quad(2 ; 30 \mathrm{mg}, \quad 0.025 \mathrm{mmol})$ and $\mathrm{Co}_{2}(\mathrm{CO})_{8}(22 \mathrm{mg}, 0.064 \mathrm{mmol})$ were dissolved in $n$-hexane $(35 \mathrm{ml})$ and the solution was stirred at ambient 
temperature for $1 \mathrm{~h}$. The solvent was evaporated and the residue was subjected to TLC, with $\mathrm{CH}_{2} \mathrm{Cl}_{2} / n$-hexane $(1: 4, \mathrm{v} / \mathrm{v})$ as eluent. Isolation of the first and second brown bands afforded $\left[\mathrm{Os}_{3}(\mathrm{CO})_{9}\left(\mathrm{C}_{28} \mathrm{H}_{40}\right)\right]\left[\mathrm{Co}_{2}(\mathrm{CO})_{6}\right]_{2}$ $(9 ; 18 \mathrm{mg}, 41 \%)$ and $\left[\mathrm{Os}_{2}(\mathrm{CO})_{6}\left(\mathrm{C}_{28} \mathrm{H}_{40}\right)\right]\left[\mathrm{Co}_{2}(\mathrm{CO})_{6}\right]_{2}$ (10; $10 \mathrm{mg}, 27 \%$ ), respectively.

\subsection{1. $\left[\mathrm{Os}_{3}(\mathrm{CO})_{9}\left(\mathrm{C}_{28} \mathrm{H}_{40}\right)\right]\left[\mathrm{Co}_{2}(\mathrm{CO})_{6}\right]_{2}(\mathbf{9})$}

IR $\left(\mathrm{CH}_{2} \mathrm{Cl}_{2}, v_{\mathrm{CO}}\right): 2104 \mathrm{w}, 2084 \mathrm{~m}, 2040 \mathrm{~s}, 1998 \mathrm{vs}$, $1966 \mathrm{~m}, 1914 \mathrm{w} \mathrm{cm}{ }^{-1} .{ }^{1} \mathrm{H}$ NMR $\left(\mathrm{CD}_{2} \mathrm{Cl}_{2}, 23{ }^{\circ} \mathrm{C}\right): 3.22-$ $1.27\left(\mathrm{~m}, \mathrm{CH}_{2}\right)$ ppm. ${ }^{13} \mathrm{C}\left\{{ }^{1} \mathrm{H}\right\}$ NMR $\left(\mathrm{CD}_{2} \mathrm{Cl}_{2}, 23{ }^{\circ} \mathrm{C}\right)$ : 201.1 (CO-Co), 177.7, 176.0, 175.9 (CO-Os), 168.0, $129.9\left(\mu-\mathrm{C}_{4} \mathrm{Os}\right), 99.1,98.9\left(\mathrm{C} \equiv \mathrm{C}-\mathrm{Co}_{2}\right), 44.0,34.4$, $33.9,33.3,32.5,31.3,30.9,30.8,29.2,28.8\left(\mathrm{CH}_{2}\right) \mathrm{ppm}$.

\subsection{2. $\left[\mathrm{Os}_{2}(\mathrm{CO})_{6}\left(\mathrm{C}_{28} \mathrm{H}_{40}\right)\right]\left[\mathrm{Co}_{2}(\mathrm{CO})_{6}\right]_{2}(\mathbf{1 0})$}

IR $\left(\mathrm{CH}_{2} \mathrm{Cl}_{2}, v_{\mathrm{CO}}\right): 2080 \mathrm{~m}, 2040 \mathrm{~s}, 1998 \mathrm{vs}, 1960 \mathrm{~m}$ $\mathrm{cm}^{-1}$. ${ }^{1} \mathrm{H}$ NMR $\left(\mathrm{CD}_{2} \mathrm{Cl}_{2}, 23{ }^{\circ} \mathrm{C}\right): 3.13-1.27\left(\mathrm{~m}, \mathrm{CH}_{2}\right)$ ppm. ${ }^{13} \mathrm{C}\left\{{ }^{1} \mathrm{H}\right\}$ NMR $\left(\mathrm{CD}_{2} \mathrm{Cl}_{2}, 23{ }^{\circ} \mathrm{C}\right): 200.1(\mathrm{CO}-\mathrm{Co})$, 184.1, 179.0, 176.0 (CO-Os), 155.7, $123.5\left(\mu-\mathrm{C}_{4} \mathrm{Os}\right)$, 98.9, $98.7\left(\mathrm{C} \equiv \mathrm{C}-\mathrm{Co}_{2}\right), 42.7,34.8,34.6,33.8,33.6$, $31.4,30.9,29.6,29.1,29.0\left(\mathrm{CH}_{2}\right) \mathrm{ppm}$.

\subsection{Structure determination for 10}

The Crystal of $\mathbf{1 0}$ suitable for an X-ray diffraction study was mounted in a thin-walled glass capillary and aligned on the Bruker Smart ApexCCD diffractometer with graphite-monochromated $\mathrm{Mo} \mathrm{K} \alpha$ radiation $(\lambda=0.71073 \AA)$. The data was collected at $150 \mathrm{~K}$. All data were corrected for the effects of absorption. The structure was solved by the direct method and refined by full-matrix least-square on $F^{2}$. The program used was the SHELXTL package [13]. All non-hydrogen atoms were refined with anisotropic displacement parameters. Hydrogen atoms were included but not re-

Table 2

Crystal data and refinement details for $\mathbf{1 0}$

\begin{tabular}{ll}
\hline Formula & $\mathrm{C}_{46} \mathrm{H}_{40} \mathrm{Co}_{4} \mathrm{O}_{18} \mathrm{Os}_{2}$ \\
\hline$T(\mathrm{~K})$ & $150(1)$ \\
Crystal system & Monoclinic \\
Space group & $P 2_{1} / c$ \\
Unit cell dimensions & \\
$a(\AA)$ & $8.8537(5)$ \\
$b(\AA)$ & $14.8788(8)$ \\
$c(\AA)$ & $39.035(2)$ \\
$\beta\left({ }^{\circ}\right)$ & $94.382(2)$ \\
$V\left(\AA^{3}\right)$ & $5127.2(5)$ \\
$Z$ & 4 \\
$D_{\text {calc }}\left(\mathrm{g} \mathrm{cm}^{-3}\right)$ & 1.939 \\
$F(000)$ & 2880 \\
$\mu\left(\mathrm{mm}^{-1}\right)$ & 6.271 \\
$\theta$ range $\left(^{\circ}\right)$ & $1.05-27.50$ \\
$R_{1}$ & 0.0569 \\
$w R_{2}$ & 0.1020 \\
GOF on $F^{2}$ & 1.004 \\
\hline
\end{tabular}

fined. A summary of relevant crystallographic data is provided in Table 2.

\section{Supplementary material}

Crystallographic data for the structural analysis of $\mathbf{1 0}$ has been deposited with the Cambridge Crystallographic Data Centre, CCDC No. 231492. Copy of this information may be obtained free of charge from: The Director, CCDC, 12 Union Road, Cambridge, CB2 1EZ, UK (fax.+44(1223)336033 or e-mail: deposit@ccdc.cam. ac.uk or www: http://www.ccdc.cam.ac.uk).

\section{Acknowledgement}

We are grateful for support of this work by the National Science Council of Taiwan.

\section{References}

[1] (a) M. NakagawaTopics in Nonbenzenoid Aromatic Chemistry, vol. 1, Hirokawa Publishing Co., Tokyo, 1973;

(b) F. Sondheimer, Acc. Chem. Res. 5 (1972) 81;

(c) R. Gleiter, W. Schäfer, Acc. Chem. Res. 23 (1990) 369;

(d) W.J. Youngs, C.A. Tessier, J.D. Bradshaw, Chem. Rev. 99 (1999) 3153.

[2] (a) F. Vögtle, Cyclophane Chemistry: Synthesis, Structures and Reactivity, Wiley, Chichester, UK, 1993;

(b) D.J. Cram, J.M. Cram, Container Molecules and Their Guests, The Royal Society of Chemistry, Lodon, 1994;

(c) R. Gleiter, M. Merger, Angew. Chem. Int. Ed. Engl. 36 (1997) 2426;

(d) R.B. King, A. Efraty, J. Am. Chem. Soc. 94 (1972) 3021;

(e) R.B. King, M.N. Ackermann, J. Organomet. Chem. 67 (1974) 431 ;

(f) C.M. Adams, E.M. Holt, Organometallics 9 (1990) 980.

[3] (a) B.J. Rausch, R. Gleiter, F. Rominger, J. Chem. Soc. Dalton Trans. (2002) 2219;

(b) M.-A. Hsu, W.-Y. Yeh, G.-H. Lee, S.-M. Peng, J. Organomet. Chem. 588 (1999) 32;

(c) M.-A. Hsu, W.-Y. Yeh, G.-H. Lee, S.-M. Peng, Inorg. Chim. Acta 294 (1999) 232.

[4] (a) K.E. Drexler, Molecular Machinery, Manufacturing and Computation, Wiley, New York, 1992;

(b) S. Onaka, M. Otsuka, Chem. Lett. (1995) 269;

(c) D.F. Shriver, H.D. Kaesz, R.D. Adams, The Chemistry of Metal Cluster Complexes, VCH, New York, 1990;

(d) A.J. Amoroso, B.F.G. Johnson, J. Lewis, A.D. Massey, P.R. Raithby, W.T. Wong, J. Organomet. Chem. 440 (1992) 219;

(e) P. Braunstein, L.A. Oro, P.R. Raithby, Metal Clusters in Chemistry, Wiley-VCH, Weinheim, Germany, 1999;

(f) W.-Y. Yeh, C.-Y. Wu, L.-W. Chiou, Organometallics 18 (1999) 3547;

(g) N.T. Lucas, E.G.A. Notaras, S. Petrie, R. Stranger, M.G. Humphrey, Organometallics 22 (2003) 708;

(h) M. Hidai, S. Kuwata, Y. Mizobe, Acc. Chem. Res. 33 (2000) 46; (i) S. Leininger, B. Oelenyuk, P.J. Stang, Chem. Rev. 100 (2000) 853.

[5] W.-Y. Yeh, M.-A. Hsu, S.-M. Peng, G.-H. Lee, Organometallics 18 (1999) 880. 
[6] W.-Y. Yeh, T.-W. Shiue, S.-M. Peng, G.-H. Lee, Organometallics 22 (2003) 2990.

[7] E. Rosenberg, J. Bracker-Novak, R.W. Gellert, S. Aime, R. Gobetto, D. Osella, J. Organomet. Chem. 365 (1989) 163.

[8] (a) W.-Y. Yeh, S.C.N. Hsu, S.-M. Peng, G.-H. Lee, Organometallics 17 (1998) 2477;

(b) P.J. Harris, J.A.K. Howard, S.A.R. Knox, R.P. Phillips, F.G.A. Stone, P. Woodward, J. Chem. Soc. Dalton Trans. (1976) 377

(c) R.P. Dodge, O.S. Mills, V. Schomaker, Proc. Chem. Soc. London (1963) 380.
[9] J.W. Steed, J.L. Atwood, Supramolecular Chemistry, Wiley, New York, 2000.

[10] D.F. Shriver, M.A. Drezdzon, The Manipulation of Air-Sensitive Compounds, second ed., Wiley, New York, 1986.

[11] R. Gleiter, R. Merger, B. Treptow, W. Wittwer, G. Pflasterer, Synthesis (1993) 558.

[12] D. Braga, F. Grepioni, E. Parisini, B.F.G. Johnson, C.M. Martin, J.G.M. Nairn, J. Lewis, M. Martinelli, J. Chem. Soc. Dalton Trans. (1993) 1891.

[13] G.M. Sheldrick, SHELXTL-97, University of Göttingen, Germany, 1997. 